\title{
A STUDY ON PROFILE AND LIFE STYLE OF BINGE EATING PEOPLE
}

\author{
L. UMA DEVI ${ }^{1} \&$ V. KAVITHA KIRAN ${ }^{2}$ \\ ${ }^{I}$ Professor and Head, Department of Human development and Family studies, \\ College of Home science, ANGRAU, Guntur, Andhra Pradesh, India \\ ${ }^{2}$ Research associate, Department of Human development and Family studies, \\ College of Home science, ANGRAU, Guntur, Andhra Pradesh, India
}

\begin{abstract}
Illness characterized by severe distress and concern about body weight or shape describe eating disorder. It means inadequate or excessive food intake, which can ultimately damage a well being of the individual. Binge Eating Disorder is the name of an eating disorder, in which a person is unable to prevent himself or herself from eating large amounts of food, often in a mindless state and in a short space of time; and the eating feels out of control. Compulsive eating describes the eating pattern of individuals, who feel that their eating is out of control and they are addicted to food leading to weight gain. People, who describe themselves as compulsive eaters feel that they cannot control their eating, and thus they end up eating more than they need. As a result, compulsive overeaters usually struggle to control their weight. Compulsive overeaters have cravings that they cannot master, and may over eat small or large amounts of food, or just pick and nibble some of the time. The objective of present research is, to study the profile of binge eating disorder people to understand their life style. The sample consisted of 55 eating disorder population in Hyderabad. The data about their demographic profile, life style and eating habits was collected through questionnaire developed by the investigator. KEYWORDS: Depression and binge eating are strongly linked self-esteem, loneliness, and body dissatisfaction
\end{abstract}

Received: Jun 10, 2017; Accepted: Jul 07, 2017; Published: Jul 20, 2017; Paper Id.: IJESRAUG20176

\section{INTRODUCTION}

When the world is dealing with hunger, there is another set of population, who suffer from eating disorder. Eating disorders are actually serious and often fatal illnesses that cause severe disturbances to a person's eating behaviors. Obsessions with food, body weight, and shape may also signal an eating disorder. Common eating disorders include anorexia nervosa, bulimia nervosa, and binge-eating disorder. People with binge-eating disorder lose control over his or her eating. As a result, people with binge-eating disorder often are overweight or obese. Eating unusually large amounts of food in a specific amount of time and feeling distressed, ashamed, or guilty about eating. They frequently diet, possibly without weight loss. Depression and binge eating are strongly linked. Many binge eaters are either depressed or have been before; others may have trouble with impulse control and managing and expressing their feelings. Low self-esteem, loneliness, and body dissatisfaction may also contribute to binge eating

People with binge eating disorder are frequently overweight or obese. This can lead them to feel chronically depressed about the way they look. After succumbing to an episode of binge eating, they may feel disgusted with themselves, worsening their depression. Binge eating episodes lead to obesity which, in turn, causes depression owing to weight stigma, poor self-esteem and reduced mobility. Depression may also lead to obesity as 
such people tend to engage in "emotional binge eating" to deal with the pain of rejection, have poor sleep patterns and turn into couch potatoes. Apart from depression and stress, other causes of binge eating are lack of confidence, loneliness, family history (related to genes) and hormonal deficiency. Binge-eating disorder is also defined as uncontrollable, excessive eating, followed by feelings of shame and guilt.

\section{OBJECTIVES}

The objective of present research is to study the profile of binge eating disorder people to understand their life style

\section{METHODOLOGY}

The present study was conducted in Hyderabad, a sample of 55 obese people were selected. The data about their demographic profile, life style and eating habits was collected through questionnaire developed by the investigator

\section{RESULTS}

The data collected using the schedules and standardized scales was scored, analyzed and presented in the following tables.

Table 1: Profile of the Sample

\begin{tabular}{|c|c|c|c|c|c|c|c|}
\hline \multirow{2}{*}{ Dimension } & \multirow{2}{*}{ Range } & \multirow{2}{*}{$\frac{\text { Frequency }}{\mathrm{N}}$} & \multirow{2}{*}{$\begin{array}{c}\text { Percentage } \\
\%\end{array}$} & \multicolumn{2}{|c|}{ Male } & \multicolumn{2}{|c|}{ Female } \\
\hline & & & & $\mathrm{N}=\mathbf{2 0}$ & $\%$ & $\mathrm{~N}=\mathbf{3 0}$ & $\%$ \\
\hline \multirow[t]{4}{*}{ Age } & $23-28$ & 20 & $40 \%$ & 6 & $30 \%$ & 14 & $46.6 \%$ \\
\hline & $29-34$ & 23 & $46 \%$ & 8 & $40 \%$ & 15 & $50 \%$ \\
\hline & $35-40$ & 4 & $8 \%$ & 3 & $24 \%$ & 1 & $3.3 \%$ \\
\hline & $>40$ & 3 & $6 \%$ & 3 & $24 \%$ & - & - \\
\hline \multicolumn{8}{|l|}{ Gender } \\
\hline & Male & 20 & $40 \%$ & - & - & - & - \\
\hline & Female & 30 & $60 \%$ & - & - & - & - \\
\hline \multicolumn{8}{|c|}{ Marital status } \\
\hline & Married & 32 & $64 \%$ & 14 & $70 \%$ & 18 & $60 \%$ \\
\hline & Unmarried & 18 & $36 \%$ & 6 & $30 \%$ & 12 & $40 \%$ \\
\hline
\end{tabular}

The table 1 presents information about the general profile of the sample selected. From the table, it can be pointed out that $40 \%$ i.e. 20 of which $12 \%$ men and $28 \%$ women are in age group of $23-28 \mathrm{yrs}, 46 \%$ i.e. 23 (16\% males \&30\% females) in 29-34years age group, while $8 \%$ in 35-40yrs and very less $6 \%$ are above 40 years. The sample consisted of $40 \%$ males and $60 \%$ females. The sample consists of $64 \%$ i.e. 32 were married of which $28 \%$ are men and $36 \%$ women. The percentage of unmarried is $36 \%$ (12\%of men and $24 \%$ of women)

Table 2: Distribution of Sample According to their Occupational Status

\begin{tabular}{|l|l|c|c|c|c|c|c|}
\hline \multicolumn{1}{|c|}{ Dimension } & Frequency & Percentage & \multicolumn{2}{c|}{ Males } & \multicolumn{2}{c|}{ Females } \\
\hline \multicolumn{2}{|c|}{} & 18 & $36 \%$ & 3 & $6 \%$ & 15 & $30 \%$ \\
\hline a. & Degree & 32 & $64 \%$ & 17 & $34 \%$ & 15 & $30 \%$ \\
\hline b. & Post graduates\& Engineers & 32 & N & $\%$ & N & $\%$ \\
\hline Working status Status & Employed & 40 & $80 \%$ & 18 & $36 \%$ & 22 & $44 \%$ \\
\hline a. & 10 & $20 \%$ & 2 & $4 \%$ & 8 & $16 \%$ \\
\hline b. & unemployed & 29 & $58 \%$ & 14 & $28 \%$ & 15 & $30 \%$ \\
\hline Occupational status & Software & 7 & $14 \%$ & - & - & 7 & $14 \%$ \\
\hline a. & Teachers &
\end{tabular}




\begin{tabular}{|l|l|c|c|c|c|c|c|}
\hline \multicolumn{7}{|c|}{ Table 2: Contd., } \\
\hline c. & Sales executives & 4 & $8 \%$ & 4 & $8 \%$ & - & - \\
\hline d. & Students & 4 & $8 \%$ & 2 & $4 \%$ & 2 & $4 \%$ \\
\hline e. & Home makers & 6 & $12 \%$ & - & - & 6 & $12 \%$ \\
\hline Income level & 24 lakhs per year & 26 & $52 \%$ & 9 & $18 \%$ & 11 & $22 \%$ \\
\hline a. & 25-40lakhs per year & 14 & $28 \%$ & 5 & $10 \%$ & 14 & $28 \%$ \\
\hline b. & Above 40 lakhs per year & 10 & $20 \%$ & 6 & $12 \%$ & 5 & $10 \%$ \\
\hline c.
\end{tabular}

The occupational profile of the sample presented in the table above reveals that majority i.e. $64 \%$ are post graduates and engineers, while 18 i.e. $36 \%$ are only graduates. In this, $15 \%$ of women and $34 \%$ of men are postgraduate while $15 \%$ of women and $6 \%$ of men are graduates. Of the total sample, $80 \%$ are employed and $20 \%$ are not working. In men sample, $36 \%$ are employed and $6 \%$ are not working while $44 \%$ of women selected are employed while $16 \%$ are unemployed. The sample consisted of soft ware professional mostly (58\%), teachers (14\%) while $8 \%$ are sales executives, $8 \%$ students and $12 \%$ are home makers. The men sample in the study $28 \%$ are software professionals, $8 \%$ sales executives and $4 \%$ are students. The selected female samples $30 \%$ are in software, $14 \%$ are teachers, $4 \%$ students and $12 \%$ homemakers. The study reveals that majority of the sample $52 \%$ (26) have income of 24lakhs per years while $28 \%$ earn up to $24-40$ lakhs and $20 \%$ i.e 10 of them have income above 40lakhs. The study reveals that $18 \%$ of males and $22 \%$ of females are earning up to 241 lakhs per year, $10 \%$ of male and $28 \%$ of female sample income level is between 25-40lakhs per year while $12 \%$ of men and $10 \%$ of women selected for the study have income of more than 40lakhs per year.

Table 3: Nutritional Status of the Respondents

\begin{tabular}{|l|c|c|c|c|c|c|c|}
\hline \multirow{2}{*}{ Attributes } & \multirow{2}{*}{ Range } & \multirow{2}{*}{ Frequency } & \multirow{2}{*}{ Percentage } & \multicolumn{2}{|c|}{ Male } & \multicolumn{2}{c|}{ Female } \\
\cline { 5 - 8 } & & & & $\mathbf{N}=\mathbf{2 0}$ & $\mathbf{\%}$ & $\mathbf{N = 3 0}$ & $\mathbf{\%}$ \\
\hline \multirow{3}{*}{ Height (cms) } & $140-150$ & 5 & $10 \%$ & 3 & $15 \%$ & 2 & $6.6 \%$ \\
\cline { 2 - 8 } & $151-16$ & 9 & $18 \%$ & 5 & $25 \%$ & 4 & $13.3 \%$ \\
\cline { 2 - 8 } & $161-170$ & 16 & $32 \%$ & 5 & $25 \%$ & 11 & $36.6 \%$ \\
\cline { 2 - 8 } & $171-185$ & 19 & $38 \%$ & 6 & $30 \%$ & 13 & $43.3 \%$ \\
\hline \multirow{3}{*}{ Weight(kgs) } & $65-75$ & 5 & $10 \%$ & 3 & $15 \%$ & 2 & $6.6 \%$ \\
\cline { 2 - 8 } & $76-85$ & 13 & $26 \%$ & 5 & $25 \%$ & 8 & $26.6 \%$ \\
\cline { 2 - 8 } & $86-95$ & 13 & $26 \%$ & 6 & $30 \%$ & 7 & $23.3 \%$ \\
\cline { 2 - 8 } & $96-110$ & 19 & $38 \%$ & 6 & $30 \%$ & 13 & $43.3 \%$ \\
\hline BMI & $25-29.9$ & 8 & $16 \%$ & 3 & $15 \%$ & 5 & $16.6 \%$ \\
\hline Over weight & $30-34.99$ & 27 & $54 \%$ & 12 & $60 \%$ & 15 & $50 \%$ \\
\hline Obese I & $35-39.99$ & 15 & $30 \%$ & 5 & $25 \%$ & 10 & $33.3 \%$ \\
\hline Obese II
\end{tabular}

Information about nutritional status of the respondents presented in the table above points out height of $38 \%$ samplei.e 19 is between $171 \mathrm{cms}-185 \mathrm{cms}, 34 \% 161 \mathrm{cms}-170 \mathrm{cms}$ while the height of $18 \%$ is between $151 \mathrm{cms}-160 \mathrm{cms}$ and $10 \%$ have height ranging from $140-150 \mathrm{cms}$. The height $6 \%$ males and $4 \%$ females is between $140-150 \mathrm{cms}$, sample $10 \%$ men and $8 \%$ women height is found to be between $151-160 \mathrm{cms}$, the height of $14 \%$ males and $20 \%$ females is between $161-$ $170 \mathrm{cms}$ and the height of $24 \%$ women and $14 \%$ men selected is between $171-180 \mathrm{cms}$. The weight of majority of the selected sample is between $97-110 \mathrm{kgs}, 24 \% 86-96 \mathrm{kgs}$ and $26 \%$ have weight ranging from $76-85 \mathrm{kgs}$, while $16 \%$ are $65-$ $75 \mathrm{kgs}$ weight. The weight of $12 \%$ males and $4 \%$ females is between $65-75 \mathrm{kgs}$, sample of $10 \%$ men and $16 \%$ women were weighing between $76-85 \mathrm{kgs}$, the weight of $14 \%$ of males and $10 \%$ females selected is around $86-96 \mathrm{kgs}$ where as $20 \%$ of the selected women and $14 \%$ of men weight is between $97-110 \mathrm{kgs}$. 
The calculated BMI reveals that $16 \%$ have BMI $27-30 \mathrm{~kg} / \mathrm{m}^{2}, 54 \% 30-33 \mathrm{~kg} / \mathrm{m}^{2}$ and $30 \%$ of the sample BMI is $34-$ $37 \mathrm{~kg} / \mathrm{m}^{2}$. From the study, it can be pointed out those $6 \%$ men and 10\% women BMI between $27-30$ and $24 \%$ men and $30 \%$ women BMI is between 30-33 while the BMI of $20 \%$ females and $10 \%$ males is around 34-37. The WHO recommendations given in the table shows that BMI between 25-29.9 is considered as overweight, while BMI of 30 and more is obese. The study shows that all the selected sample weight, height and BMI indicate that they are obese.

Table 4: Life Style of the Respondents

\begin{tabular}{|c|c|c|c|c|c|c|c|}
\hline \multirow{2}{*}{ Attributes } & \multirow{2}{*}{ Sub Divisions } & \multirow[t]{2}{*}{ Frequencies } & \multirow[t]{2}{*}{ Percentage } & \multicolumn{2}{|c|}{ Male } & \multicolumn{2}{|c|}{ Female } \\
\hline & & & & $\mathbf{N}$ & $\%$ & $\mathbf{N}$ & $\%$ \\
\hline \multirow{2}{*}{ Life style } & Sedentary & 50 & $100 \%$ & 20 & $40 \%$ & 30 & $60 \%$ \\
\hline & Moderate & - & - & - & - & - & - \\
\hline \multirow{3}{*}{$\begin{array}{l}\text { Working } \\
\text { hours }\end{array}$} & 9am-5pm & 8 & $16 \%$ & 2 & $4 \%$ & 6 & $12 \%$ \\
\hline & 3pm-1am & 22 & $44 \%$ & 9 & $18 \%$ & 13 & $26 \%$ \\
\hline & 9pm-5am & 20 & $40 \%$ & 9 & $18 \%$ & 11 & $22 \%$ \\
\hline \multirow{4}{*}{$\begin{array}{l}\text { Eating } \\
\text { outside }\end{array}$} & Frequently/daily & 29 & $58 \%$ & 13 & $26 \%$ & 16 & $32 \%$ \\
\hline & twice a week & 13 & $26 \%$ & 5 & $10 \%$ & 8 & $16 \%$ \\
\hline & Once a week & 5 & $10 \%$ & 2 & $4 \%$ & 3 & $6 \%$ \\
\hline & Once in month & 3 & $6 \%$ & - & - & 3 & $6 \%$ \\
\hline \multirow{3}{*}{$\begin{array}{l}\text { Food } \\
\text { preferred }\end{array}$} & Vegetarian & 4 & $8 \%$ & - & - & 4 & $8 \%$ \\
\hline & Non vegetarian & 8 & $16 \%$ & 6 & $12 \%$ & 2 & $4 \%$ \\
\hline & Both & 38 & $76 \%$ & 14 & $28 \%$ & 24 & $48 \%$ \\
\hline
\end{tabular}

The life style of the respondents presented reveal that all the selected sample both males and females selected have sedentary life style and majority $(44 \%)$ of them have work times around 3 pm-1am while $40 \%$ work timings are from 9pm-5am. The selected $4 \%$ males and $12 \%$ females had regular work timings of $9 \mathrm{am}-5 \mathrm{pm}$. The work timings of $18 \%$ men and $26 \%$ women are from $3 \mathrm{pm}$ to $1 \mathrm{am}$, whereas $18 \%$ of selected men $22 \%$ women work from $9 \mathrm{pm}$ to $5 \mathrm{am}$. It was interesting to note that more than half of selected sample i.e. $58 \%$ (i.e. $26 \%$ of males and $32 \%$ women) eat outside food very frequently (almost daily), 26\% (10\% men and 16\% women) twice a week, 10\% (4\% men and 6\% women) once in a week and $6 \%$ women once in month. The most preferred food of $76 \%$ sample both vegetarian and non vegetarian,i.e $28 \%$ men and $48 \%$ women while $16 \%$ (12\% men and $4 \%$ women) prefer only non vegetarian and $8 \%$ of the women like to have vegetarian food.

Table 5: Obesity Related Facts of the Respondents

\begin{tabular}{|c|c|c|c|c|c|c|c|}
\hline \multirow{2}{*}{ Attributes } & \multirow{2}{*}{ Dimensions } & \multirow{2}{*}{$\frac{\text { Frequency }}{\mathrm{N}}$} & \multirow{2}{*}{$\frac{\text { Percentage }}{\%}$} & \multicolumn{2}{|c|}{ Male } & \multicolumn{2}{|c|}{ Female } \\
\hline & & & & $\mathbf{N}$ & $\%$ & $\mathbf{N}$ & $\%$ \\
\hline \multirow{4}{*}{$\begin{array}{l}\text { Onset of } \\
\text { obesity }\end{array}$} & Childhood & - & - & - & - & - & - \\
\hline & Adolescence & 8 & $16 \%$ & 2 & $4 \%$ & 6 & $12 \%$ \\
\hline & Adulthood & 26 & $52 \%$ & 14 & $28 \%$ & 12 & $24 \%$ \\
\hline & Recently (last 6 months) & 16 & $32 \%$ & 4 & $8 \%$ & 12 & $24 \%$ \\
\hline \multirow{2}{*}{$\begin{array}{l}\text { Family history } \\
\text { of obesity }\end{array}$} & Yes & 17 & $34 \%$ & 5 & $10 \%$ & 12 & $24 \%$ \\
\hline & No & 33 & $66 \%$ & 15 & $30 \%$ & 18 & $36 \%$ \\
\hline \multirow{4}{*}{$\begin{array}{l}\text { Health issues } \\
\text { related to } \\
\text { obesity }\end{array}$} & Thyroid & 20 & $40 \%$ & 7 & $14 \%$ & 13 & $26 \%$ \\
\hline & Diabetes & 18 & $36 \%$ & 10 & $20 \%$ & 8 & $16 \%$ \\
\hline & Blood pressure & 8 & $16 \%$ & 3 & $6 \%$ & 5 & $10 \%$ \\
\hline & None & 4 & $8 \%$ & - & - & 4 & $8 \%$ \\
\hline
\end{tabular}

The obesity related information of the respondents reveal interesting facts that $52 \%$ (28\% men and $24 \%$ women selected) of them are obese only after reaching adulthood while $32 \%$ i.e. $8 \%$ of males and $24 \%$ females recently became obese and only $16 \%$ of which $4 \%$ are males and $12 \%$ females are obese from their adolescence. It was surprising to note 
from the study that none of them are obese from their childhood days.

It was surprising to note that out of the $66 \%$, males are $30 \%$ and $36 \%$ are females, who didn't have family history of obesity. Only $17 \%$ (10\% males and $24 \%$ females) had family history of obesity.

The study further notes that health related problems like thyroid are found in $40 \%$ of which, $14 \%$ are males and $26 \%$ females, a sample of $36 \%$ (20\% men and 16\% women) have diabetes, $16 \%$ (6\% men and $10 \%$ women) are suffering from Blood Pressure due to obesity.

Table 6: Binge Eating Habits of the Respondents

\begin{tabular}{|l|l|c|c|c|c|c|c|}
\hline \multirow{2}{*}{ Eating Habits } & \multirow{2}{*}{ Dimensions } & Frequencies & Percentages & \multicolumn{2}{|c|}{ Male } & \multicolumn{2}{|c|}{ Female } \\
\cline { 2 - 7 } & & $\mathbf{N}$ & $\mathbf{\%}$ & $\mathbf{N}$ & $\%$ & $\mathbf{N}$ & $\%$ \\
\hline \multirow{2}{*}{$\begin{array}{l}\text { No. of meals per } \\
\text { day }\end{array}$} & Two & 5 & $10 \%$ & 2 & $4 \%$ & 3 & $6 \%$ \\
\cline { 2 - 7 } & Three & 27 & $54 \%$ & 7 & $14 \%$ & 20 & $40 \%$ \\
\cline { 2 - 8 } & Four & 18 & $36 \%$ & 11 & $22 \%$ & 7 & $14 \%$ \\
\hline \multirow{4}{*}{$\begin{array}{l}\text { Circumstance of } \\
\text { overeating }\end{array}$} & Stress & 23 & $46 \%$ & 13 & $26 \%$ & 10 & $20 \%$ \\
\cline { 2 - 8 } & Alone & 4 & $8 \%$ & - & - & 4 & $8 \%$ \\
\cline { 2 - 8 } & Boredom & 3 & $6 \%$ & - & - & 3 & $6 \%$ \\
\cline { 2 - 8 } & Depression & 20 & $40 \%$ & 7 & $14 \%$ & 13 & $26 \%$ \\
\hline \multirow{3}{*}{$\begin{array}{l}\text { Feeling after } \\
\text { over eating }\end{array}$} & Guilt & 12 & $24 \%$ & 4 & $8 \%$ & 8 & $16 \%$ \\
\cline { 2 - 8 } & Anxious & 8 & $16 \%$ & 3 & $6 \%$ & 5 & $10 \%$ \\
\cline { 2 - 8 } & Happy & 28 & $56 \%$ & 11 & $22 \%$ & 17 & $34 \%$ \\
\cline { 2 - 8 } & Nothing & 2 & $4 \%$ & 2 & $4 \%$ & - & - \\
\hline \multirow{2}{*}{$\begin{array}{l}\text { Time of } \\
\text { snacking }\end{array}$} & Evening & 3 & $6 \%$ & - & - & 3 & $6 \%$ \\
\cline { 2 - 8 } & Night & 21 & $42 \%$ & 8 & $16 \%$ & 13 & $26 \%$ \\
\cline { 2 - 8 } & Mid night & 26 & $52 \%$ & 12 & $24 \%$ & 14 & $28 \%$ \\
\hline
\end{tabular}

The binge eating habits of the respondents presented in the table points out that $54 \%$ (14\% males and $40 \%$ females) of them have three meal pattern, $36 \%$ of which $22 \%$ are men and $14 \%$ women have four meals a day and $10 \%$ i.e. $4 \%$ males and $6 \%$ females have two meals per day. The study finds that the circumstances during which the respondent overeat is $46 \%$ (26\% men and $14 \%$ women) under stress, and the study points out that binge eating habit occurs during the depression in $14 \%$ men and $26 \%$ women i.e40\% of the selected sample. And $8 \%$ of women binge eat when alone and $6 \%$ of women overeat because of boredom. The feelings of respondents after over eating is found to guilt in $24 \%$ ( $8 \%$ males and $16 \%$ females), A sample of $16 \%$ of which $6 \%$ are men and $10 \%$ women feel anxious and majority of the selected sample 56\%(22\% males,34\% females) feel happy after overeating, while $4 \%$ of men have no feeling after binge eating. The time of snacking (indulging in binge eating) of respondents is mostly midnight (52\%) of which $24 \%$ males and $28 \%$ females and during nights $(42 \%)$ out of which $16 \%$ are males and $26 \%$ females and $6 \%$ of women snack in evenings while none of the males selected snack in evening.

Table7: Gender Differences in Binge Eating Habits

\begin{tabular}{|l|c|c|c|c|c|c|}
\hline \multirow{2}{*}{ Attributes } & \multicolumn{2}{c|}{ Male } & \multicolumn{2}{c|}{ Female } & \multirow{2}{*}{ T Value } & \multirow{2}{*}{ P Value } \\
\cline { 2 - 6 } & Mean & SD & Mean & SD & & \\
\hline No. of meals per day & 2.7895 & .78733 & 2.4000 & .62146 & 1.926 & $.06 \mathrm{NS}$ \\
\hline Circumstance of overeating & 1.4737 & .96427 & 1.9000 & 1.18467 & 1.315 & $.195 \mathrm{NS}$ \\
\hline Feeling after over eating & 1.7368 & 1.24017 & 2.0667 & 1.17248 & -.938 & $.353 \mathrm{NS}$ \\
\hline Time of snacking & 4.0000 & .74536 & 3.8000 & .55086 & 1.079 & $.286 \mathrm{NS}$ \\
\hline
\end{tabular}

There are no significant differences in mean scores of male and female binge eating habits 


\section{CONCLUSIONS}

Binge eating disorder is one of psychological eating disorders, which needs to be addressed urgently. The study reveals that life style is major factor of developing this disorder. The study concludes that unusual work timings, sedentary life styles, more income levels and comforts are mostly deciding factors of binge eating disorder. Indulging in overeating often results in obesity, due to which, other health related problems like thyroid, diabetes, blood pressure. Unusual body weight makes the individual to feel guilt, depressed and lowers self esteem. Though weight reduction centers help to reduce the weight, there is always a chance for getting back to binge eating. This disorder is psychological, so it needs to be intervened with Cognitive behavior therapy with behavior modification, which would help to conquer this psychological eating disorder and stop its reoccurrence.

\section{REFERENCES}

1. Burrows GD, Olver JS, Bosanac P, Norman TR, 2004.Depression and comorbidity. World Journal Biological Psychiatry 5:18

2. Borges MBF, Jorge MR, Morgan CM, Silveira DX, 2002. Binge eating disorder in Brazilliab women on weight loss programme. Obes Res 10:1127-1134.

3. Fontenelle LF, Mendlowicz V, de Menezes GB, Palpebaum M, Godoy Matos A et al 2003. Psychiatric comorbidity in Brazilian sample of patients with binge eating disorder. Psychiatry Res 19: 189-194.

4. Kolotkin RL, Westman EC, Ostbye T, Crosby RD, Eisenson HJ, Binks M. 2004. Does binge eating disorder impact weight related quality of life? Obes Res 12: 999-1005

5. Malevani J, Mobascher J, Cordes J, Mobascher A, 2007. Differential diagnosis of cogulation abnormalities in borderline personality disorder.World Journal Biological Psychiatry 10:1-3 